\title{
РЕДАКТОРСЬКІ ПОСАДИ \\ В УМОВАХ ІНФОРМАЦІЙНОЇ СПЕЦІАЛІЗАЦІЇ
}

๑ О. М. Левчук, к.філол.н., доцент, НТУУ «КПІ”, Київ, Україна

В статье обозначены актуальные тренды развития профессиональных специализаций издательского дела и редактирования в условиях сетевой коммуникации. Обобщены проблемы депрофессионализации издательской отрасли и показаны новообразующиеся компетенции, которые требуются от редакторов как универсальных специалистов на рынке информационно-организационных услуг, который массированно развивается в условиях неочевидности. Явственно демонстрируется общность таких всемирных ныне требований к сотрудникам информационной отрасли, как способность самостоятельно разрешать проблемы, умение общаться, актуальная компетентность в области новых информационных технологий и педагогические знания, которые вполне соответствуют принятому теперь в Украине профилю подготовки специалиста по издательскому делу и редактированию.

The article stated current trends of publishing and editing professional specializations in network communication. It generalized problem of the lack of professionalism in publishing industry and showed newly formed competences that are required from editors as versatile specialists on information and logistics services market, which develops impetuously in non-obviousness. This article manifested global requirements for information workers, such as the ability to solve problems, ability to communicate, the actual competence of the new information technolo-

gies and pedagogical knowledge. Such competences fully describe a modern profile of specialist publishing and editing in Ukraine.

Стан освіти і актуальної практики в індустріально-інформаційну епоху характеризується повсякчасною потребою в набутті варіативного інструментарію для роботи та функціонування спеціаліста за швидкозмінних умов. Це в найближчій перспективі передбачає побудову його кар'єрної траєкторії за жорстким механічно-репродуктивним алгоритмом.
Як писав поет і філософ Олексій Цвєтков у підводці до радіопередачі «Шостий континент» на радіо «Свобода» у середині 1990-х: «Не шукайте майбутнього на книжкових ятках майбутнє вже настало.

Усі відстані зведені до нуля, запізнення покасовані, всі засоби мовлення й спілкування сплавлені воєдино у всесвітньому палаці Інформації». 
Всесвітня Мережа, про яку йдеться, зробила середовище обігу і набуття знань гостро конкурентним. Часом інформація не встигне ще вийти в публічний простір, а вже застаріває, жодна концепція чи картина явища тепер не мають канонічних версій - знання перебуває в постійному русі поновлення, доповнення, коригування, рекомбінації з новими висновками.

Отже, навчатися якогось конкретного фаху чи здобути кваліфікацію в таких умовах уже неможливо, як кажуть, «раз і назавжди». Відтепер цей процес нагадує знамениту максиму авіаконструктора Олега Антонова «Десять разів - спочатку». Тож для всіх, хто входить до світу фаховості через вищу освіту, у професійній самореалізації нагальною постала стратегія, альтернативна звичному в післярадянських країнах отримуванню диплома на виплат (часом, грошима, адмінресурсом). Новим професіоналам мережевого суспільства, до яких передовсім належать редактори актуальних спеціалізацій , потрібна вже не статусна, а стартова освіта з таким набором компетенцій, щоб із їх допомогою зручно було спеціалізуватися щораз під нову посаду. Адже у фахів доби інтернету дедалі все меншає корпоративного герметизму i все більше виділяється запитаних опцій: конкретизованих під задачу знань-умінь-здатностей. I ефективний фахівець прийдешнього, яке вже настало, побудує себе сам, особисто, бо поверх його базової освіченості надбу- довуватимуться актуальні в конкретний момент кар'єри предметні знання і компетенції здатності виконувати роботу відповідно до вимог посади, на яку працівника вповноважили.

Редакторові на передньому краї інформаційного суспільства за теперішніх потреб ринку видавничо-інформаційних послуг не уникнути в своєму професійному розвиткові трьох речей: до/переучування, постійного міжфахового діалогу та інтердисциплінарної співдії. Скажімо так: ніхто й не працює вже суто «за спеціальністю», яка зазначена у нього в дипломі про освіту. Всі професіонали актуальних галузей практики, і редактори тут не виняток, працюють чітко «під проблему» чи на певну задачу, а це вимагає радше уміння будувати стосунки i досягати результатів у групі, аніж застосовувати напрацьовані фахові алгоритми в стандартних виробничих ситуаціях. Бо й стандартних виробничих ситуацій залишається все менше: людське суспільство вступило в період навальної інновативності, тож замовником і користувачем професійних знаньумінь стає сам суб'єкт навчально-професійного процесу, а не держави чи провідні корпорації. Власне, і виробничі стосунки 3 директивних (згори вниз, я начальник - ти мовчи і роби, що кажуть) хутко еволюціонують в горизонтальні, а це передбачає проектну взаємо- і співдію спеціалістів, чия компетентність визначається тим, що їх професійна підготовка давно не тотожна їх освіті, отже - штиб та напрями, траєкторії цієї 
підготовки визначають (та й забезпечують) вони самі.

Таким «самосформованим» суб'єктам-фахівцям неможливо наказувати, вони схильні люто сперечатися, обстоюючи свою фахову опінію, бо розуміють про зв'язок речей у світі організаційних схем та прагматичних рішень набагато більше за будь-якого топ-менеджера. Власне, адміністратори і наймають фахівців з метою, щоб ті вирішили проблеми, яких начальники не здатні подужати особисто. Скажімо, в Україні після 2008 р. масово економлять на видавничо-редакційному персоналі, ціна якого на ринку праці значно знизилася. Тож якщо один відповідальний на редакторській посаді не $є$ компетентним у чомусь, його радше замінять аналогічним відповідальним 3 шуканою компетенційною опцією. Втім, конкуренція на інновативному ринку інформаційних продуктів та послуг навально загострилася, тому нині спеціалістів-редакторів наймають уже не на позиції челяді для обслуговування начальствених візій, а - суто заради отримання конкретного результату в умовах, про які мало що відомо - бо умови теж $€$ у процесі становлення. Як написав був пусковий редактор Леонід Бершидський на Снобі.ру, «професіонал (редакторської справи) - не раб, він робить те, що вважає за правильне, а не те, що йому наказують» [2].

Особливої ваги в жорстких і непевних умовах праці набирає здатність незалежного суб'єктапрофесіонала до творчої діяльності, а особливо - володіння актуальним і унікальним досвідом $з$ провадження творчих проектів. І це нині стосується не самих лише редакційних гуманітаріїв чи представників творчих професій. Активно творче начало $€$ натепер відправним у будь-чиїй і будьякій праці, бо фаховий поступ у XXI столітті - це простування наосліп незайманими інформаційними теренами, на яких невідомо, що очікує за поворотом. Опрацьовувати не знані доти проблеми фахівцям під навалою інформації доводиться в міру їх надходження, реагувати на виклики мережевого світу слід негайно, щоб мати змогу в найкоротший час прийняти оптимальне рішення.

Так, департамент праці США як держави - лідера не на ринку товарів, а на ринку ідей і проблемних рішень - вже у 2008 р. виокремив список універсальних навичок, що їх найбільше цінують американські працедавці в своїх співробітниках.

Це а) здатність самостійно розв'язувати проблеми, б) вміння спілкуватися з людьми, в) актуальна компетентність 3 нових інформаційних технологій (комп'ютерна грамотність) та г) педагогічні знання [4].

Додамо, що всіма цими перевагами настановчо володіють фахові редактори, адже це перелік базових умов для успішної редакторської діяльності. Достатньо порівняти їх 3 переліком компетенцій, на які взоруються у ВПІ НТУУ «КПІ» при підготовці фахівців за спеціальністю «Видавнича справа та редагування». 
Отже, за становлення Київської школи літературного редагування (1964-1989) її фундатор професор Роман Іванченко виокремив такі універсальні фахові вимоги до роботи редактора:

1. Уміти аналізувати й прогнозувати розвиток суспільноекономічних та культурних процесів як у власній країні, так і в масштабах цивілізаційного регіону та світу.

2. Мати осяжну ерудицію 3 якнайбільшої кількості галузей людського знання.

3. Бути інтуїтивно грамотним, тобто не тільки затямити норми літературних мов, з якими працює, а й відчувати тенденції їхнього розвитку, постійно аналізувати усну «мову вулиці» та мовлення найбільших комунікаційних середовищ (друк, ТБ-радіо, тепер - інтернету, соціальних мереж за інтересами тощо).

4. Досконало знати (і принагідно вивчати в деталях) ту галузь літератури, з текстами якої працює на даний момент.

5. Бути обізнаним 3 історії, теорії й методики редагування, вміти коректно доносити редакторські вимоги і рекомендації.

6. Мати докладне уявлення щодо процесів перетворення рукопису/авторського оригіналу на тираж будь-якого різновиду видання.

7. Знати основи економіки й маркетингу книжкової продукції, іiї піару та промоції, художнього оформлення видань.

8. Вміти професійно користуватися сучасною редакційновидавничою технікою і технологіями, удосконалювати свої методичні та організаторські здібності.

9. Всіляко сприяти впровадженню сучасних технологій у видавничу практику, за їх допомогою роз'яснювати громадськості проблеми та можливості видавничої галузі.

10. Знати логічні й психологічні особливості творчого процесу, бути в змозі самому виступити в ролі автора.

До того ж розвиток новітніх медій за умов глобалізації вимагає від сучасного редакторауніверсала соціально-комунікативних технологій зважати також на відносно свіжі тенденції, притаманні веб-середовищу та гіперпросторові, а саме:

гіпертекстуальність - системний зв'язок між окремими документами за допомогою вбудованих у текст гіперпосилань (тоді його можна бачити вглиб, а не тільки лінійнопослідовно);

інтерактивність - багатобічний інформаційний обмін в одному фізичному середовищі як 3 окремими користувачами, так і з величезними консолідованими аудиторіями (нині має в основному одночасний, синхронний характер);

мультимедійність - матеріально зреалізована медіаконвергенція всіх відомих каналів передачі інформації в єдину цілість; дає змогу передавати повідомлення одразу в усіх знакових системах (вербальній, графічній, звуковій, фото-відео, анімаційній...) [6].

Що до останнього, то редакторський фах нині, як жоден 3 гуманітарних (крім журналістики, яка цією конвер- 
генцією розмивається і переходить у контент-менеджмент, блогінг чи «громадянський журналізм»), активно конвергує 3 новітніми інформаційними технологіями. Вікіпедія, втім, зафіксувала на початок 2013 р. тільки три варіації редакторського фаху за родом діяльності: редактор літературний, редактор художній, редактор фільмів. Функціонально посаду редактора у Вікіпедії.ру поділено також на редактора книжкового видавництва і більд-редактора, а статусний концепт «головний редактор" там тільки заявлений як рубрика, що її вміст «іще не написано». Це викликає подив, якщо не гнів, тому що асортимент посадових інструкцій для чинних запитів на працевлаштування в Мережі (кадрові та сайти з рекрутингу) видає дещо іншу картину редакторської запитаності на глобалізованому ринку праці:

- спеціалізація за функціоналом - редактор-диктор новин радіо, редактор ТБ-програм, науковий редактор, літературний редактор, випусковий редактор, технічний редактор, контент-менеджер - редактор сайту, відповідальний редактор - копірайтер,

- за керівною компетентністю і статусом - головний редактор, заступник головного редактора, завідувач редакційновидавничого відділу, молодший редактор, коректор.

Нещодавні публікації на спеціалізованих медіапорталах додають до цього списку ще контрольного редактора, який вичитує начисто за лінійним літературним своїм колегою та видавничим коректором у випадку, якщо текст породжений методом краудсорсингу (віддалена робота групи медійників під контролем відповідального редактора проекту через Мережу - переклад, рерайт, база даних тощо), а також фактчекера - редактора, відповідального за коректність фактажу. Гостьовий редактор виконує нині радше менеджерські функції, веде базу гостей та експертів на ТБ і радіо, є не оптимізатором контенту, а продюсером стосунків «на позір» ефірної аудиторії [12].

Додаткові соціально-комунікаційні різновиди редакторської праці з'явилися на обрії протягом останніх місяців: це інформаційний та арт-куратори - перший відповідає за «фільтрування базару», відкидаючи інформаційний мотлох у спецресурсах даних, другий аналог критика з розширеними менеджерськими повноваженнями, який редакційно опікується гуманітарними та природничо-науковими «матеріалами довгої хвилі» (їх нині витиснуто поза зону медіаінформаційного виробництва як комерційно неперспективний «неформат») [10].

У зоні кричущої актуальності, з огляду на мультимедійну специфіку медіасередовища, зараз перебувають редактор блогу та редактор соціальних мереж ці кадрові позиції вже зафіксовано, наприклад, у організаційних схемах конвергентної редакції «Кореспондент.нет» [3]. Цікаво, що останній майже нічим не нагадує вузькофункціональну 
посаду модератора сайту, який покликаний здійснювати поточну цензуру на форумах та стежити за коректністю комунікаційної поведінки відвідувачі інет-ресурсів. Але чітко редакторські функції покладено, приміром, на продюсера програм, який, згідно з доступними в Мережі посадовими вимогами, поєднав у собі функції контент-менеджера, кореспондента і літературного та випускового редакторів [13].

Технічний письменник (технопис) $є$ універсальною редакторсько-перекладацькою спеціалізацією з ухилом у рерайтинг (творче переказування), причому переклад він здійснює як міжмовний, так і внутрімовний - коли потрібно донести актуальну інформацію до неспеціалізованої чи малопідготовленої аудиторії (фахові інструкції до програмних продуктів, посібники 3 адаптації «...для чайників» тощо) [7]. Яскравим представником цієї вузької профілізації в редакторському фаху нині виступає випускник нашої кафедри Валерій Аксак, автор популярних посібників з комп'ютерної теорії і практики [11]. Що ж до професії «рерайтер», то вона попри те, що є етично дражливою з погляду охорони авторського права, зовсім не вимагає усталеної компетентності з редакторської оптимізації текстів: на цю кадрову позицію в основному добирають студентів-гуманітарів чи відносно грамотних «технарів», бо їх іще рано (чи - недоцільно) допускати до друкарської коректури. Ще скромнішої компетентності - на рівні хорошого слуху, уваги і грамотності при високій швидкості друкування - вимагають від транскрібера - розшифрувальника-упорядника аудіозаписів та інтерв'ю.

Натомість роботу прес-секретаря часто пропонують авторитетним редакторам з високих статусних щаблів або журналістам-репортерам бездоганної репутації, які мають значний організаційний досвід і сталий авторитет. Інша справа, що на цій посаді репутацію можна зіпсувати безнадійно, тоді назад у практичне редагування і журналістику вороття з неї немає (О. Громницька, Г. Стеців-Герман, І. Ванникова). Натомість B'ячеславу Мойсеєву вдалося не просто зберегти репутацію журналіста і редактора, будучи прес-секретарем О. Антонова. Він, по суті, заснував, обґрунтував і викладає вітчизняну версію коректного піар-менеджменту (без чорних, білих і рябих піарів), особливо при цьому наголошуючи конфлікт інтересів між «Стосунками 3 громадськістю» та журналістикою і редакторською справою (як між контррозвідкою та розвідкою, див. його підручники «Паблік рілейшнз» та «Журналістика і журналісти»).

Безумовно, сфера докладення редакторських умінь розширюватиметься дедалі все активніше, з виходами не тільки в менеджмент-маркетинг медіасистем, а й у референтуру, аналітику/консалтинг і діловодство, юриспруденцію та логістику (літературні агенти). Як завважує літагент Анастасія Лестер, її спеціалізація ділиться 
на два різновиди робіт: скаут і власне агент. Скаут - це найманий працівник на зарплаті, таки собі «засланий козачок», що працює одразу на кілька видавництв, що не конкурують. Його задача не прозівати нового автора чи прецедентно цікавого тексту, тобто читати багато видань і консультувати з цього приводу працедавців. Тим часом агент, читаючи стільки ж, як скаут, не пов'язаний жодними умовами, працює за гонорар як експерт, бо представляє і обстоює передовсім інтереси автора. Отже, його компетенція мусить хутко поширюватися зараз на мережеві комунікації, де контент циркулює безоплатно, натомість автори кревно зацікавлені в його монетизації [8].

3 розвитком соціальних мереж виникла потреба в координаторах медіапроектів для різних громадянських ініціатив, які самоорганізовуються на платформі Веб 2.0 («Свідомо», «Чесно», «Майдан.орг», Карта лісових пожеж (РФ), Мережа допомоги постраждалим у Кримську (РФ) тощо). І, як увиразнення загальної тенденції, головний редактор «Корреспондента» Ю. МакГаффі нещодавно виставила вакансію мультимедіа-редактора для порталу «Кореспондент.нет», зразків кваліфікаційного опису якої ще не існує - тож його належить робити кожного разу під потреби окремої редакції. Зазвичай 3 такої ситуації виходять, аналізуючи внутріредакційні регламенти (стайлбук, порадник, книга стилю тощо) на предмет кваліфікаційних характеристик та компетенцій, що мусять бути притаманні редакторам тільки цього конкретного ЗМК.

Так само небагато можна ще сказати про нововідкриту позицію SMM-менеджера: за приблизною кваліфікаційною характеристикою, це інтердисциплінарна спеціалізація, що виникла останніми місяцями на перетині високих технологій, мережевих комунікацій, редакторської справи та організаційно-операційного менеджменту. Це універсальний спеціаліст, здатний якісно керувати людьми й процесами в межах певної соціальної платформи (скажімо, бренда). Він зазвичай веде акаунти і групи в соцмережах, просуваючи в інтернеті певний проект. На хвилі «революції в соцмережах» працедавці до того ж почали запитувати відеоредакторів та редакторів інфографіки, спеціалістів з громадянської журналістики (нетворкерів), створювачів електронних книг (E-Book Creator) [1].

Можна 3 певністю передбачити, що український Класифікатор професій ДК 003:2010 названі професії не фіксуватиме з огляду хоча б на швидкість, 3 якою Веб 2.0 трансформує інформаційний бізнес та видавничу галузь: те, що місяць тому здавалося «крутою фішкою» і запитане як актуальний фах, через рік імовірно вже вважатимуть архівною версією. Спеціалізації Веб 2.0 блискавично змінюватимуть ринок праці, підкоряючись запитові швидкоплинної медіата технологічної практики, але триматимуться в рейтингах 
зарплат хіба до появи ще більш спеціалізованих варіантів обслуговування конвергентного середовища. Втім, редакторів 3-поміж інших спеціалістів виграшно вирізняє іманентна адаптивність цієї професії (актуальні варіації посад з вебу відповідальний редактор, медичний редактор, редактор-організатор). Як щоразу редактор пристосовується до унікальних параметрів тексту й графіки, працює 3 неповторною особистістю - автором, так само він здатен і має настанову «входити» в будь-який інший фах через контент у функції універсального медіатора, комунікатора та упопулярнювача, є практичним психологом і методистом. На користь видавничій галузі не йде хіба що сильний перегин редакторського фаху на бік рекламно-організаційних комунікацій, про що й попереджає працедавців і самих редакторів генеральний директор «Інтерфаксу-Україна» О. Мартиненко [9].

Але наразі Класифікатор професій ДК 003:2010 пропонує українським шукачам кар'єрного успіху відносно консервативний перелік напрямів виробничої діяльності. У стосунку до редакторського та сміжних із ним фахів їх вибірка виглядає так:

- видавнича діяльність, видання книг, видання довідників і каталогів, видання газет/журналів, надання інформаційних послуг, оброблення даних, розміщення інформації на вебвузлах і пов'язана з ними діяльність, діяльність інформаційних агентств, діяльність громадських/професійних ор- ганізацій, діяльність профспілок, діяльність релігійних/політичних організацій, діяльність екстериторіальних організацій і органів.

Абсолютно поза межами регламенту лишаються такі актуальні напрями технологізованої медіапрактики, як пошукові технології (пошукова оптимізація CEO), агрегація контенту, технології авторства (візуалізація наративів), технології сумісної роботи в конвергентному середовищі і подібні інновації.

Утім, медіадійсність у стані інформаційного вибуху тепер вимагає від медійників не стільки керувати потоками даних, скільки фільтрувати їх від інформаційного бруду та сміття, які дедалі спричиняють медіаінфляцію - втрату довіри та уваги аудиторій до сенсу переданих через медії повідомлень. Тому медіаконсультанти, на замовлення відфільтровуючи з потоку даних тільки актуальне і нове, сильно полегшують функціонерам прийняття рішень і економлять їх час. Часу на перекваліфікацію, як завжди, у всіх обмаль, тому провідні фахівці 3 медіаграмотності підказують: нового спеціаліста для інформаційно-комунікаційної роботи слід орієнтувати на дещо інший штиб фахової поведінки уже в процесі його навчання. Професор Генрі Дженкінс з Університету Південної Каліфорнії стверджує, що інтердисциплінарна медіаосвіта тепер повинна формувати у прийдешніх та чинних фахівців мережевої епохи 11 основних умінь:

- Грати, Володіти мовами, Моделювати ситуації, Візуалізу- 
вати, Орієнтуватися в медіях, Домовлятися, Мислити колективно, Класифікувати набуті знання, Висловлювати судження, Обстоювати авторські права, Виконувати кілька завдань одночасно.

Та по-справжньому успішний медіадіяч віднині мусить володіти головним умінням інформаційної доби: розуміти, як саме соціальні інститути та практики впливають на поточне формування і Функціонування медіа ресурсів [5].

Цей потік даних уже ніколи не перерветься, його зростання навальне та безнастанне, тож професійною місією редактора XXI століття варто визнати потребу готувати суспільство до нових ризиків та нових, розширюваних можливостей використання медій як пересічного ре- сурсу, звичного у повсякденному спілкуванні. Адже звикання притлумлює критичність у сприйнятті інформації: захистний механізм критики не дає втратити пильність, орієнтує у довкіллі, забезпечує адекватну оцінку подій, явищ і намірів. Тому редактор як носій сформованої при професійній підготовці превентивної критичності видається кращою $з$ кандидатур для контролю та вирівнювання гуманітарних балансів у швидкозмінній реальності медіапрактик. Його фаховий універсалізм дозволяє вчасно реагувати на поточні проблеми в ЗМК та соцмережах, будучи широко адаптовуваний до багатьох професійно-медійних потреб, як свідчить огляд поданих тут посадових варіацій редакторської професії.

1. 11 новых вакансий, которые появятся в СМИ в ближайшем будущем // Сетевой репортер [Електронний ресурс]. - Режим доступу : http://setreporter.blogspot.com/2011/08/11.html. 2. Бершидский Л. Купить главного редактора / Л. Бершидский // Snob RU [Електронний ресурс]. - Режим доступу : http://www.redactor.in.ua/personas/3474.html. 3. Ганжа Л. МакГаффи Юлия «Объединение редакций у нас не пошло» / Л. Ганжа // Редакторский портал [Електронний ресурс]. - Режим доступу : http://www.redactor.in.ua/ personas/3289.html. 4. Дахно І. І. Ділова кар'єра / І. І. Дахно. - К. : ЦУЛ, 2011. - С. 528 с. 5. Дженкінс Г. Від нової медіаграмотності до нової медіакомпетентності / Г. Дженкінс // Телекритика [Електронний ресурс]. - Режим доступу : http://osvita.mediasapiens.ua/material/1578. 6. Квіт С. Масові комунікації : підручник / С. Квіт. К. : Вид. дім «Києво-Могилянська академія», 2008. - С. 154-155. 7. Климентова О. Творцы прогресса / О. Климентова // Работа и учёба. 2005. - № 42. - С. 20-21. 8. Лестер А. Українські видавці - нафталін і провінція / А. Лестер // Життя. Українська правда [Електронний ресурс]. Режим доступу : http://life.pravda.com.ua/society/2012/02/16/95580/. 9. Мартыненко А. Их настоящее - это наше будущее / А. Мартыненко // Редакторский портал [Електронний ресурс]. - Режим доступу : http://www.redactor.in.ua/personas/3569.html. 10. Штернберг Дж. Будущее журналистики - за информационными кураторами / Дж. Штернберг // Mashable.com [Електронний ресурс]. - Режим доступу : http://www.planetasmi.ru/component/blog/comments.html?pid=6568. 11. Електронний peсурс. - Режим доступу : http://www.aksak.kiev.ua/. 12. Електронний ресурс. - Режим доступу : http://www.profguide.ru/professions/guest-edi- 
tor.html. 13. Електронний ресурс. - Режим доступу : http://www.work.ua/ ua/documents/job-descriptions/journalists/312/.

1. 11 novyh vakansij, kotorye pojavjatsja v SMI v blizhajshem budushhem // Setevoj reporter [Elektronnyi resurs]. - Rezhym dostupu : http://setreporter.blogspot.com/2011/08/11.html. 2. Bershidskij L. Kupit' glavnogo redaktora / L. Bershidskij // Snob RU [Elektronnyi resurs]. - Rezhym dostupu : http://www.redactor.in.ua/personas/3474.html. 3. Ganzha L. MakGaffi Julija «Ob\#edinenie redakcij u nas ne poshlo» / L. Ganzha // Redaktorskij portal [Elektronnyi resurs]. - Rezhym dostupu : http://www.redactor.in.ua/ personas/3289.html. 4. Dakhno I. I. Dilova kar'iera / I. I. Dakhno. - K. : TsUL, 2011. - S. 528 s. 5. Dzhenkins H. Vid novoi mediahramotnosti do novoi mediakompetentnosti / H. Dzhenkins // Telekrytyka [Elektronnyi resurs]. - Rezhym dostupu : http://osvita.mediasapiens.ua/material/1578. 6. Kvit S. Masovi komunikatsii : pidruchnyk / S. Kvit. - K. : Vyd. dim «Kyievo-Mohylianska akademiia", 2008. - S. 154-155. 7. Klimentova O. Tvorcy progressa / O. Klimentova // Rabota i uchjoba. - 2005. - № 42. - S. 20-21. 8. Lester A. Ukrainski vydavtsi - naftalin i provintsiia / A. Lester // Zhyttia. Ukrainska pravda [Elektronnyi resurs]. - Rezhym dostupu : http://life.pravda.com.ua/society/2012/02/16/95580/. 9. Martynenko A. Ih nastojashhee - jeto nashe budushhee / A. Martynenko // Redaktorskij portal [Elektronnyi resurs]. Rezhym dostupu : http://www.redactor.in.ua/personas/3569.html. 10. Shternberg Dzh. Budushhee zhurnalistiki - za informacionnymi kuratorami / Dzh. Shternberg // Mashable.com [Elektronnyi resurs]. - Rezhym dostupu : http://www. planetasmi.ru/component/blog/comments. html? pid=6568. 11. Elektronnyi resurs. - Rezhym dostupu : http://www.aksak.kiev.ua/. 12. Elektronnyi resurs. - Rezhym dostupu : http://www.profguide.ru/professions/guest-editor.html. 13. Elektronnyi resurs. - Rezhym dostupu : http://www.work.ua/ua/documents/job-descriptions/journalists/312/.

Рецензент - Л. П. Шендерівська, ст. викладач, НТУУ «КП|» 